\title{
Effect of Planting Dates and Mulching on Growth and Flowering of Tuberose (Polianthes tuberosa L.) cv. Sikkim Selection
}

\author{
Nikita Vaid*, S.V.S. Chaudhary, B.P. Sharma, Y.C. Gupta and Gaurav Chauhan \\ Department of Floriculture and Landscape Architecture, Dr YS Parmar University of \\ Horticulture and Forestry Nauni, Solan 173230 Himachal Pradesh, India \\ *Corresponding author
}

\section{Keywords \\ Planting dates, Mulching, Tuberose, Spike, bulb \\ Article Info \\ Accepted: \\ 04 April 2019 \\ Available Online: \\ 10 May 2019}

\section{A B S T R A C T}

"Effect of planting dates and mulching on growth and flowering of tuberose (Polianthes tuberosa L.) cv. Sikkim Selection" was studied at the Research farm of Department of Floriculture and Landscape Architecture, Dr YS Parmar University of Horticulture and Forestry, Nauni, Solan (HP) during 2016-2017. The experiment was laid out in Randomized Block Design (Factorial) having 12 treatment combinations with three planting dates i.e. $20^{\text {th }}$ May, $15^{\text {th }}$ June and $10^{\text {th }}$ July along with 3 mulching material i.e. dry grass mulch, black plastic mulch and transparent plastic mulch with control treatment and each treatment was replicated thrice. The results showed that $20^{\text {th }}$ May planting gave the best results in terms of all the growth and flowering parameters and tuberose plants mulched with black plastic established significantly with superior plant and yield parameters. Amongst various interactions crop planted on $20^{\text {th }}$ May with black plastic mulch showed best results in various growth and flowering parameters like early sprouting of bulb, earliest spike emergence, maximum spike length, maximum rachis length, maximum number of florets per spike, maximum fresh weight of spike, maximum duration of flowering, largest sized bulb. Based on the findings $20^{\text {th }}$ May planting and black plastic mulch were found to be best treatments.

\section{Introduction}

Tuberose is an important flower crop grown in India mainly for its beautiful and fragrant cut flowers as well as loose flowers, belongs to family Amaryllidaceae and is commonly known as Rajnigandha or Nishigandha. It is native to Mexico. Tuberose is most important commercial flower among bulbous ornamental. They are valued much by the aesthetic world for their beauty and fragrance.
It has long been cherished for the aromatic oils extracted from its fragrant flowers. There is high demand for tuberose concrete and absolute in the international markets which fetch a very good price. Tuberose can successfully be grown in pots, borders, beds and commercially cultivated for its various uses, as for making artistic garlands, floral ornaments and bouquets. Its importance among the commercially grown flowers is due to its potential for cut flower trade, long 
vase life and essential oil industry (Singh, 1995). Total area under tuberose cultivation is 7.77 thousand ha and production of loose flower is 40.22 thousand metric tons and that of cut flower is 13.90 thousand metric tons in India (Anonymous, 2015). The cultivation of tuberose on commercial basis is being taken around big cities in India. With the improvement in standard of living of the people, the demand for flowers is increasing by leaps and bounds. To meet this demand, it is being cultivated on large scale in different states of the country. For getting higher yield with quality flowers, time of planting is one of the most important factors. Vegetative growth and quality of tuberose is improved by proper planting time which also satisfies the consumer's demands (Muhammad et al., 2013). According to Sadhu and Bose (1973), the tuberose in India is generally planted in February-March in plains and April-May in hills and February planting in plains increased the vegetative growth of tuberose. Planting time varies from place to place because of differences in photoperiods, temperatures and light intensity.

Mulching is a very useful technique for protecting the roots of plant from heat, cold injuries and mulching cover the surface around the plants with aim to create congenial conditions for the growth of plants and has an influence on various aspects of soil environment and crop requirements. Physically, mulches prevent rapid evaporation from the soil surface and reduce rapid drying which result moisture conservation. Mulching and its skilful application can lead to improved soil organic matter contents, mulching practices give positive effect on the soil biota, it increases under mulched soil environment thereby improving nutrient cycling and organic matter build-up over a period of several years and thereby improving other soil characteristics. It helps in enhancing microbial activity in the soil (Parmar et al.,
2013). It is an important technology that helps in conserving soil moisture thus reducing the irrigation requirements, act as insulation layer, increasing root development, promoting faster crop development, reducing weed population and inducing earlier harvest of crop (Mahajan et al., 2007). Beneficial effect of mulching materials on growth, flowering and yield has been reported in most of the vegetables and fruit crops. However, literature on its valuable effects on flower crops is scanty. Keeping this in view, this investigation was undertaken with the objective to find out appropriate planting date for tuberose under mid hill conditions of Himachal Pradesh and to identify suitable mulch for tuberose crop.

\section{Materials and Methods}

The present investigation entitled, "Effect of planting dates and mulching on growth and flowering of tuberose (Polianthes tuberosa L.) cv.Sikkim Selection" was carried out at the Research farm of department of Floriculture and Landscape Architecture, Dr YS Parmar University of Horticulture and Forestry, Nauni, Solan (HP) during the year 2016 and 2017. The experimental farm of the department is located in the hilly regions of Western Himalayas at an altitude of $1276 \mathrm{~m}$ amsl having latitude of $305202 \mathrm{~N}$ and longitude $701130 \mathrm{E}$. The climate is subtemperate to sub-tropical type and characterized by mild summers and cool winters. The unsprouted, healthy and disease free bulb of uniform size were planted. Proper plant to plant and row to row distance was maintained and tuberose bulbs were planted at desired depth and spacing of $25 \mathrm{~cm} \times 25 \mathrm{~cm}$ to accommodate 16 bulbs $/ \mathrm{m}^{2}$. The experiment was laid out in randomized block design with 3 replications. The treatments included three dates of planting i.e. $20^{\text {th }}$ May, $15^{\text {th }}$ June and $10^{\text {th }}$ July along with 3 mulching material i.e. black plastic mulch, dry grass mulch, 
transparent plastic mulch and control i.e. no mulch. Uniform cultural operations like; weeding, hoeing, fertilization, spraying against insect-pest and diseases and staking etc were followed for all the treatments. Data was recorded on growth, flowering and bulb attributes and subjected to statistical analysis.

\section{Results and Discussion}

Data presented in table 1 exhibited significant influence of planting dates, mulching material and their interaction on days taken for sprouting of bulbs. Among the different planting dates, minimum days taken for sprouting of bulbs (8.38 days) was recorded in $20^{\text {th }}$ May planting $\left(\mathrm{D}_{1}\right)$, whereas, maximum days taken for sprouting of bulbs (12.42 days) was recorded in $10^{\text {th }}$ July planting $\left(\mathrm{D}_{3}\right)$. As regards the effect of mulching, lesser time for sprouting of bulbs (9.06 days) was recorded in black plastic mulch $\left(\mathrm{M}_{2}\right)$, whereas, bulbs took more time for sprouting (10.92 days) without mulch $\left(\mathrm{M}_{0}\right)$.

Padaganur et al., (2005) and Khobragade et $a l .$, (1997) stated that early planting induced early sprouting while working in various cultivars of tuberose, they stated that this might be attributed to the fact that plants experienced optimum temperature and humidity during their grand growth period. Messar (2011) also reported that the soil moisture conservation under black polythene mulch is comparatively more than the other mulches, thus ensuring early sprouting of bulbs.

Data in table 2 show that spike length was positively influenced with planting dates, mulching material and their interaction. Spike length was recorded to be better in plants being planted earlier i.e. $20^{\text {th }}$ May and decreased with delay in planting. The critical examination of data presented in table 2 revealed that maximum spike length $(102.36$ $\mathrm{cm})$ was recorded in $20^{\text {th }}$ May planting $\left(\mathrm{D}_{1}\right)$, whereas, minimum spike length $(91.73 \mathrm{~cm})$ was recorded in $10^{\text {th }}$ July planting $\left(\mathrm{D}_{3}\right)$. As regards the effect of mulching, maximum spike length $(100.42 \mathrm{~cm})$ was recorded in black plastic mulch $\left(\mathrm{M}_{2}\right)$, whereas minimum spike length $(93.35 \mathrm{~cm})$ was recorded without mulch $\left(\mathrm{M}_{0}\right)$. The interaction of planting dates $\times$ mulching materials was also found to be significant. Maximum spike length (107.51 $\mathrm{cm}$ ) was recorded in $20^{\text {th }}$ May planting with black plastic mulch $\left(\mathrm{D}_{1} \times \mathrm{M}_{2}\right)$, whereas, minimum spike length $(89.40 \mathrm{~cm})$ was recorded in $10^{\text {th }}$ July planting without mulch $\left(\mathrm{D}_{3} \times \mathrm{M}_{0}\right)$ which proved statistically at par $(91.24 \mathrm{~cm}) \quad$ in $10^{\text {th }}$ July planting with transparent plastic mulch $\left(\mathrm{D}_{3} \times \mathrm{M}_{3}\right)$. These results are in close proximity with the work of Padaganur et al., (2005), Dubey and Shukla (2002), Thokchom and Singh (2015) who observed that early planting resulted in better spike length than later plantings. Messar (2011) observed maximum spike length under black plastic mulch in gladiolus.

Table 3 shows among the different planting dates and mulching materials used maximum number of spikes per plot (20.83) and (17.37) were recorded in $20^{\text {th }}$ May planting and black plastic mulch respectively and minimum number of spikes (11.83) and (14.87) was observed in $10^{\text {th }}$ July planting and without mulch respectively. The interaction of planting dates $\times$ mulching material influenced number of spikes per plot. Maximum number of spikes per plot (22.27) was recorded in $20^{\text {th }}$ May planting with black plastic mulch $\left(\mathrm{D}_{1 \times} \times\right.$ $\mathrm{M}_{2}$ ). However minimum number of spikes per plot (10.67) was recorded in $10^{\text {th }}$ July planting without mulch. Findings of Rana (2014) showed that last week of April planting improved number of spikes as compared to later plantings. Kumar et al., (2010 b) and Thokchom and Singh (2015) while working on tuberose also observed more number of spikes in early planting, the increase in 
number of spikes per plant could be attributed to early sprouting and better vegetative growth. On the other hand work of Deka and Talukdar (2017) who observed maximum number of shoots in tuberose under black plastic mulch.

Data in table 4 shows that among the different planting dates, maximum fresh weight of spike (183.93 grams) was recorded in $20^{\text {th }}$ May planting $\left(\mathrm{D}_{1}\right)$, whereas minimum fresh weight of spike (157.24 grams) was recorded in $10^{\text {th }}$ July planting $\left(\mathrm{D}_{3}\right)$. As regards the effect of mulching, maximum fresh weight of spike (175.69 grams) was recorded in black plastic mulch $\left(\mathrm{M}_{2}\right)$, whereas minimum fresh weight (165.74 grams) was recorded without mulch $\left(\mathrm{M}_{0}\right)$. The interaction of planting dates $\times$ mulching material influenced fresh weight of spike. Maximum fresh weight of spike (190.37 grams) was recorded in $20^{\text {th }}$ May planting with black plastic mulch $\left(\mathrm{D}_{1 \times} \times \mathrm{M}_{2}\right)$, however minimum fresh weight of spike (152.52 grams) was recorded in $10^{\text {th }}$ July planting without mulch at different level of significance. Fresh weight of spike was recorded maximum in early planting and decreased with delayed planting. The results are in close agreement with the findings of Gurav et al., (2005) who observed that weight of flower stalk was significantly maximum in
April planted crop. Maximum fresh weight of spike was found in black plastic mulch. The results got support from the findings of Messar (2011) while working on gladiolus.

The data related to number of florets per spike in table 5 shows that planting dates, mulching material and their interaction significantly affected the number of florets per spike. Among the different planting dates tested, maximum number of florets per spike (31.25) was recorded in $20^{\text {th }}$ May planting $\left(D_{1}\right)$, whereas, minimum number of florets per spike (18.00) was recorded in $10^{\text {th }}$ July planting $\left(\mathrm{D}_{3}\right)$ which proved to be significantly different. As regards the effect of mulching, maximum number of florets per spike (26.94) was recorded in black plastic mulch $\left(\mathrm{M}_{2}\right)$, whereas minimum number of florets (21.64) was recorded without mulch $\left(\mathrm{M}_{0}\right)$ which varied significantly. The interaction of planting dates $\times$ mulching material influenced number of florets per spike. Maximum number of florets per spike (34.33) was recorded in $20^{\text {th }}$ May planting with black plastic mulch $\left(D_{1} \times M_{2}\right)$, however, minimum number of florets per spike (15.67) was recorded in $10^{\text {th }}$ July planting without mulch which proved statistically at par (16.67) in $10^{\text {th }}$ July planting in transparent plastic mulch $\left(\mathrm{D}_{3} \times \mathrm{M}_{3}\right)$.

Table.1 Effect of planting dates and mulching material on days taken for sprouting of bulb of tuberose (Polianthes tuberosa L.) cv. 'Sikkim Selection'

\begin{tabular}{|c|c|c|c|c|c|}
\hline \multirow[b]{2}{*}{$\begin{array}{l}\text { Planting } \\
\text { Dates }\end{array}$} & \multicolumn{4}{|c|}{ Days taken for sprouting of bulb } & \multirow[b]{2}{*}{ Mean } \\
\hline & $\begin{array}{l}\text { No mulch } \\
\qquad\left(\mathrm{M}_{0}\right)\end{array}$ & $\begin{array}{l}\text { Dry grass } \\
\text { mulch } \\
\left(\mathrm{M}_{1}\right)\end{array}$ & $\begin{array}{l}\text { Black plastic } \\
\text { mulch } \\
\left(\mathrm{M}_{2}\right)\end{array}$ & $\begin{array}{l}\text { Transparent } \\
\text { plastic mulch } \\
\qquad\left(\mathrm{M}_{3}\right)\end{array}$ & \\
\hline $20^{\text {th }}$ May $\left(D_{1}\right)$ & 8.96 & 8.43 & 7.53 & 8.60 & 8.38 \\
\hline $15^{\text {th }}$ June $\left(\mathrm{D}_{2}\right)$ & 9.96 & 9.43 & 8.77 & 10.46 & 9.66 \\
\hline $10^{\text {th }}$ July $\left(D_{3}\right)$ & 13.83 & 12.17 & 10.87 & 12.80 & 12.42 \\
\hline Mean & 10.92 & 10.01 & 9.06 & 10.62 & \\
\hline
\end{tabular}


Table.2 Effect of planting dates and mulching material on spike length of tuberose (Polianthes tuberosa L.) cv. 'Sikkim Selection'

\begin{tabular}{|c|c|c|c|c|c|}
\hline \multirow[b]{2}{*}{$\begin{array}{l}\text { Planting } \\
\text { Dates }\end{array}$} & \multicolumn{4}{|c|}{ Spike length (cm) } & \\
\hline & $\begin{array}{l}\text { No mulch } \\
\qquad\left(\mathrm{M}_{0}\right)\end{array}$ & $\begin{array}{l}\text { Dry grass } \\
\text { mulch } \\
\left(\mathrm{M}_{1}\right)\end{array}$ & $\begin{array}{c}\text { Black plastic } \\
\text { mulch } \\
\left(\mathrm{M}_{2}\right)\end{array}$ & $\begin{array}{l}\text { Transparent } \\
\text { plastic mulch } \\
\qquad\left(\mathrm{M}_{3}\right)\end{array}$ & Mean \\
\hline $20^{\text {th }}$ May $\left(D_{1}\right)$ & 97.73 & 104.28 & 107.51 & 99.92 & 102.36 \\
\hline $15^{\text {th }}$ June $\left(D_{2}\right)$ & 92.90 & 97.73 & 99.92 & 95.23 & 96.45 \\
\hline $10^{\text {th }}$ July $\left(D_{3}\right)$ & 89.40 & 92.45 & 93.82 & 91.24 & 91.73 \\
\hline Mean & 93.35 & 98.16 & 100.42 & 95.46 & \\
\hline
\end{tabular}

Table.3 Effect of planting dates and mulching material on number of spikes per plot of tuberose (Polianthes tuberosa L.) cv. 'Sikkim Selection'

\begin{tabular}{|c|c|c|c|c|c|}
\hline \multirow[b]{2}{*}{$\begin{array}{l}\text { Planting } \\
\text { Dates }\end{array}$} & \multicolumn{4}{|c|}{ Number of spikes per plot } & \multirow[b]{2}{*}{ Mean } \\
\hline & $\begin{array}{l}\text { No mulch } \\
\quad\left(\mathrm{M}_{0}\right)\end{array}$ & $\begin{array}{l}\text { Dry grass } \\
\text { mulch } \\
\left(\mathrm{M}_{1}\right)\end{array}$ & $\begin{array}{l}\text { Black plastic } \\
\text { mulch } \\
\left(\mathrm{M}_{2}\right)\end{array}$ & $\begin{array}{l}\text { Transparent } \\
\text { plastic mulch } \\
\qquad\left(\mathrm{M}_{3}\right)\end{array}$ & \\
\hline $20^{\text {th }}$ May $\left(D_{1}\right)$ & 19.43 & 21.17 & 22.27 & 20.43 & 20.83 \\
\hline $15^{\text {th }}$ June $\left(\mathrm{D}_{2}\right)$ & 14.50 & 16.33 & 16.50 & 15.33 & 15.67 \\
\hline $10^{\text {th }}$ July $\left(D_{3}\right)$ & 10.67 & 11.67 & 13.33 & 11.67 & 11.83 \\
\hline Mean & 14.87 & 16.39 & 17.37 & 15.81 & \\
\hline
\end{tabular}

Table.4 Effect of planting dates and mulching material on fresh weight of spike of tuberose (Polianthes tuberosa L.) cv. 'Sikkim Selection'

\begin{tabular}{|c|c|c|c|c|c|}
\hline \multirow[b]{3}{*}{$\begin{array}{l}\text { Planting } \\
\text { Dates }\end{array}$} & \multicolumn{4}{|c|}{ Fresh weight of spike (gram) } & \multirow{3}{*}{ Mean } \\
\hline & $\begin{array}{l}\text { No mulch } \\
\quad\left(\mathrm{M}_{0}\right)\end{array}$ & $\begin{array}{l}\text { Dry grass } \\
\text { mulch } \\
\left(\mathrm{M}_{1}\right)\end{array}$ & $\begin{array}{c}\text { Black plastic } \\
\text { mulch } \\
\left(\mathrm{M}_{2}\right)\end{array}$ & $\begin{array}{l}\text { Transparent } \\
\text { plastic mulch } \\
\qquad\left(\mathrm{M}_{3}\right)\end{array}$ & \\
\hline & & & & & \\
\hline $20^{\text {th }}$ May $\left(D_{1}\right)$ & 177.51 & 186.51 & 190.37 & 181.33 & 183.93 \\
\hline $15^{\text {th }}$ June $\left(D_{2}\right)$ & 167.17 & 171.86 & 175.16 & 168.56 & 170.69 \\
\hline $10^{\text {th }}$ July $\left(\mathrm{D}_{3}\right)$ & 152.52 & 158.93 & 161.54 & 155.99 & 157.24 \\
\hline Mean & 165.74 & 172.43 & 175.69 & 168.63 & \\
\hline
\end{tabular}


Table.5 Effect of planting dates and mulching material on number of florets per spike of tuberose (Polianthes tuberosa L.) cv. 'Sikkim Selection'

\begin{tabular}{|c|c|c|c|c|c|}
\hline \multirow[b]{2}{*}{$\begin{array}{l}\text { Planting } \\
\text { Dates }\end{array}$} & \multicolumn{4}{|c|}{ Number of florets per spike } & \multirow[b]{2}{*}{ Mean } \\
\hline & $\begin{array}{c}\text { No mulch } \\
\left(\mathrm{M}_{0}\right)\end{array}$ & $\begin{array}{c}\text { Dry grass } \\
\text { mulch } \\
\left(\mathrm{M}_{1}\right)\end{array}$ & $\begin{array}{l}\text { Black plastic } \\
\text { mulch } \\
\left(\mathrm{M}_{2}\right)\end{array}$ & $\begin{array}{c}\text { Transparent } \\
\text { plastic mulch } \\
\left(\mathrm{M}_{3)}\right.\end{array}$ & \\
\hline $20^{\text {th }}$ May $\left(D_{1}\right)$ & 28.23 & 32.30 & 34.33 & 30.13 & 31.25 \\
\hline $15^{\text {th }}$ June $\left(\mathrm{D}_{2}\right)$ & 21.03 & 23.47 & 26.16 & 21.36 & 23.00 \\
\hline $10^{\text {th }}$ July $\left(D_{3}\right)$ & 15.67 & 19.33 & 20.33 & 16.67 & 18.00 \\
\hline Mean & 21.64 & 25.03 & 26.94 & 22.72 & \\
\hline
\end{tabular}

\begin{tabular}{|c|l|}
\hline $\mathrm{CD}_{0.05 \text { for }}$ & \\
\hline Planting dates & $: 0.20$ \\
\hline Mulching material & $: 0.24$ \\
\hline Planting dates $\times$ Mulching material & $: 0.40$ \\
\hline
\end{tabular}

Table.6 Effect of planting dates and mulching material on size of bulb produced of tuberose (Polianthes tuberosa L.) cv. 'Sikkim Selection'

\begin{tabular}{|c|c|c|c|c|c|}
\hline \multirow[b]{2}{*}{$\begin{array}{l}\text { Planting } \\
\text { Dates }\end{array}$} & \multicolumn{4}{|c|}{ Size of bulb $(\mathbf{c m})$} & \\
\hline & $\begin{array}{c}\text { No mulch } \\
\left(\mathrm{M}_{0}\right)\end{array}$ & $\begin{array}{l}\text { Dry grass } \\
\text { mulch } \\
\left(\mathrm{M}_{1}\right)\end{array}$ & $\begin{array}{c}\text { Black plastic } \\
\text { mulch } \\
\left(\mathrm{M}_{2}\right)\end{array}$ & $\begin{array}{l}\text { Transparent } \\
\text { plastic mulch } \\
\left(\mathrm{M}_{3}\right)\end{array}$ & Mean \\
\hline $20^{\text {th }}$ May $\left(D_{1}\right)$ & 2.30 & 2.40 & 2.70 & 2.35 & 2.44 \\
\hline $15^{\text {th }}$ June $\left(D_{2}\right)$ & 2.29 & 2.40 & 2.47 & 2.33 & 2.37 \\
\hline $10^{\text {th }}$ July $\left(D_{3}\right)$ & 2.29 & 2.35 & 2.39 & 2.33 & 2.34 \\
\hline Mean & 2.30 & 2.38 & 2.52 & 2.34 & \\
\hline
\end{tabular}

\begin{tabular}{|c|c|}
\hline $\mathrm{CD}_{0.05 \text { for }}$ & \\
\hline Planting dates & $: 0.05$ \\
\hline Mulching material & $: 0.06$ \\
\hline Planting dates $\times$ Mulching material & $: 0.10$ \\
\hline
\end{tabular}

These results are in agreement with the findings of Padaganur et al., (2005), Gurav et al., (2005), Thokchom and Singh (2015) while working on tuberose and Kumar (2005) who observed maximum yield in April planting under Nauni, Solan conditions while working on China aster. . Maximum number of florets was observed in black plastic mulching. The results are in close agreement with the findings of Messar (2011) who observed maximum number of florets under black plastic mulch in gladiolus and Bohra et al., (2016). Table 6 shows that size of bulb produced was significantly influenced by 
planting dates, mulching material and their interaction. Among the different planting dates, maximum size of bulb $(2.44 \mathrm{~cm})$ was recorded in $20^{\text {th }}$ May planting $\left(\mathrm{D}_{1}\right)$, whereas minimum size of bulb $(2.34 \mathrm{~cm})$ was recorded in $10^{\text {th }}$ July planting $\left(\mathrm{D}_{3}\right)$ which proved statistically at par $(2.38 \mathrm{~cm})$ in $15^{\text {th }}$ June planting $\left(\mathrm{D}_{2}\right)$. The results are in accordance with the result of Thokchom and Singh (2015) who recorded diameter of largest bulb in the early date of planting at $20^{\text {th }}$ April planting. Contrary results were obtained by Zubair and Wazir (2006) who suggested that delay in planting resulted in decreased bulb diameter. Mulching influenced the bulb size significantly. Maximum size of bulb (2.52 $\mathrm{cm})$ was recorded in black plastic mulch $\left(\mathrm{M}_{2}\right)$, whereas minimum size of bulb $(2.30 \mathrm{~cm})$ was recorded without mulch $\left(\mathrm{M}_{0}\right)$ followed by $\mathrm{M}_{3}$ $(2.34 \mathrm{~cm})$. The interaction of planting dates $\times$ mulching material influenced size of bulb produced significantly. Maximum size of bulb produced $(2.70 \mathrm{~cm})$ was recorded in $20^{\text {th }}$ May planting with black plastic mulch $\left(\mathrm{D}_{1 \times} \times \mathrm{M}_{2}\right)$, However minimum size of bulb produced $(2.29 \mathrm{~cm})$ was recorded in $10^{\text {th }}$ July planting without mulch $\left(\mathrm{D}_{3} \times \mathrm{M}_{0}\right)$, followed by $(2.30$ $\mathrm{cm})$ in $\left(\mathrm{D}_{1} \times \mathrm{M}_{0}\right),(2.30 \mathrm{~cm})$ in $\left(\mathrm{D}_{2} \times \mathrm{M}_{0}\right)$, , $(2.33 \mathrm{~cm})$ in $\left(\mathrm{D}_{2} \times \mathrm{M}_{3}\right),(2.33 \mathrm{~cm})$ in $\left(\mathrm{D}_{3} \times\right.$ $\left.\mathrm{M}_{3}\right),(2.35 \mathrm{~cm})$ in $\left(\mathrm{D}_{3} \times \mathrm{M}_{1)}(2.35 \mathrm{~cm})\right.$ in $\left(\mathrm{D}_{1}\right.$ $\times M_{3)}$ and $(2.39 \mathrm{~cm})$ in $\left(D_{3} \times M_{2}\right)$. The results are in close proximity with the findings of Messar (2011) while working on gladiolus and Deka and Talukdar (2017) who observed maximum number of large sized bulbs in black polythene mulch.

\section{References}

Anonymous. 2015. State wise area and production of flowers during the year 2013- 2014 (Annexure 13), pp. 286 In: Indian horticulture data base 2015, M Saxena and CP Gandhi (eds). I G Printer Pvt. Ltd., New Delhi, India, 286p.
Bohra M, Kumar S, Singh CP and Visen A. 2016. Studies on effect of mulching materials on floral attributes of rose (Rosa spp) cv. Lahar under tarai conditions of Uttarakand state, India. Research on Crops 17:324-330.

Deka M and Talukdar MC. 2017. Effect of mulching on growth and flowering of tuberose (Polianthes tuberosa Linn.) cv. Double. Research on Crops 18:129-132.

Dubey SK and Shukla RK. 2002. Effect of planting time on tuberose. Journal of Ornamental Horticulture 5:48.

Gurav SB, Singh BR, Desai UT, Katwate SM, Kakade DS, Dhane AV and Kanade VD. 2005. Influence of planting time on yield and quality of tuberose. Indian Journal of Horticulture 62:216-217.

Khobragade RI, Damke MM, Jadhao BJ, Hedau CV. 1997. Effect of planting time and spacing on growth, flowering and bulb production of tuberose cv. Single. Punjabrao Krishi Vidyapeeth Research Journal 21:44-47.

Kumar S, Sharma J, Dahiya DS and Singh B. 2010b. Effect of time of planting on growth and flowering of tuberose. National Seminar on Recent Trends in Horticultural Crops- Issues and Strategies for Research and Development held at Hisar, India. pp. 22-24.

Kumar S. 2005. Evaluation of Cultivars, Planting Dates and $\mathrm{GA}_{3}$ on Flowering and Seed Yield on China Aster (Callistephus chinensis L. Nees). M.Sc. Thesis. Department of Floriculture and Landscape Architecture, Dr YS Parmar University of Horticulture and Forestry, Solan. 61p.

Mahajan G, Sharda R, Kumar A and Singh KG. 2007. Effect of plastic mulch on economizing irrigation water and weed control in baby corn sown by different methods. African Journal of Agricultural Research 2:19-26. 
Messar Y. 2011. Studies on Effect of Mulches and Micronutrient Foliar Sprays on Growth and Flowering in Gladioli. M.Sc. Thesis. Department of Floriculture and Landscape Architecture, Dr YSR Horticultural University, Hyderabad. 70p.

Muhammad A, Ahmad W, Ahmad KS, Shafi J, Muhammad AS, Muhammad AS, Muhammad S, Muhammad IG and Muhammad I. 2013. Effect of different planting dates on growth and development of Gladiolus grandiflorus under the ecological conditions of Faisalabad, Pakistan. Universal Journal of Agricultural Research 1:110-117.

Padaganur VG, Mokashi AN and Patil VS. 2005. Effect of planting time on growth and yield of flowers in tuberose cv. 'Single'. Karnataka Journal of Agricultural Sciences 18:551-554.

Parmar HN, Polara ND and Viradiya RR. 2013. Effect of mulching material on growth, yield and quality of watermelon (Citrullus lanatus Thunb.) cv. Kiran. Universal Journal of Agriculture Research 1:30-37.

Rana GS. 2014. Studies on Planting Time and
Spacing on Growth and Flowering of Tuberose (Polianthes tuberosa L.). M.Sc. Thesis. Department of Floriculture and Landscape Architecture, Chaudhary Charan Singh Haryana Agriculture University, India. 48p.

Sadhu MK and Bose TK. 1973. Tuberose for most artistic garlands. Indian Horticulture 18:17-20.

Singh KP. 1995. Improved production technologies for tuberose (Polianthes tuberosa L.), a review of research done in India. Indian Institute of Horticultural Research, Hessargarhatta, Banglore. pp.141-166.

Thokchom R and Singh UC. 2015. Effect of time and depth of planting on growth, flowering and yield of tuberose cv. Single. Indian Journal of Horticulture 72:581-585.

Zubair M, Wazir FK, Akhtar S and Ayub G. 2006. Planting dates affect floral characteristics of gladiolus under the soil and climatic conditions of Peshawar. Pakistan Journal of Biological Sciences 9:1669-1676.

\section{How to cite this article:}

Nikita Vaid, S.V.S. Chaudhary, B.P. Sharma, Y.C. Gupta and Gaurav Chauhan. 2019. Effect of Planting Dates and Mulching on Growth and Flowering of Tuberose (Polianthes tuberosa L.) cv. Sikkim Selection. Int.J.Curr.Microbiol.App.Sci. 8(05): 199-206. doi: https://doi.org/10.20546/ijcmas.2019.805.024 